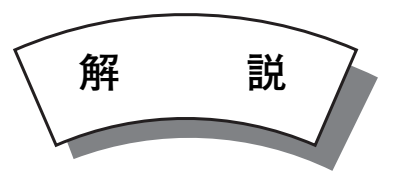

\title{
微粒子接合による高性能断熱材料の開発と材料リサイクルへの展開

\author{
High Performance Thermal Insulators Developed by using Particle \\ Bonding and its Application for Material Recycling
}

\author{
近藤 光* • 阿 部 浩也* $・$ 内藤 牧 男* \\ Akira KONDO, Hiroya ABE and Makio NAITO
}

Key Words: Particle Bonding, Thermal Insulator, Recycling, FRP

\section{1. 緒 言}

固体微粒子集合体としての粉体は、先端から基盤分野に 至るまで、ほぼあらゆる産業に用いられている。それに対 応して、ナノ粒子や各種形態の粒子作製技術の開発が進む など、わが国の粉体技術も近年大きく進歩した。その中で も、特に粒子の複合構造を制御することにより微粒子材料 を開発する試みや、作製された複合粒子をさらに集積する ことにより、多様な微細構造を制御して各種新材料を開発 する試みが、最近大きく注目されている。

筆者らはその一つの取り組みとして、粒子同士を機械的 手法により接合して複合粒子を作製する研究と、作製され た複合粒子による新材料開発を進めてきた。本法は、後述 するように加熱操作を施さずに大気圧下で粒子同士を直接 接合するものであり、シンプル、かつ省エネルギー型の製 造プロセスであると考えられる。本稿では、この機械的手 法による粒子複合化プロセスの概要を紹介するとともに、 このプロセスの応用の一つとして、高性能断熱材料の実用 化に寄与した例を紹介する。

このように異種材料を複合化することにより、これまで 様々な新材料が実用化されてきたが、今後も大幅な地球温 暖化対策、省エネルギー化が進められる中で、リサイクル による資源の再利用、それに伴うエネルギーや環境負荷の 低減がますます重要になるものと思われる。したがって、 今後材料を実用化する際には、使用後のリサイクルやその 循環利用までも視野に入れる必要がある。また、既に実用 化され、これまで幅広く利用されてきた様々な材料を、廃 棄する際にどのようにリサイクルし、また資源としてどの ように再利用していくかと言った点についても、考えるべ き時代に来ている。このような要請に対して、筆者らは材 料界面の接合に加えて、その分離という観点から、リサイ クルが困難である複合材料の新しい循環利用に向けたアプ
ローチを展開してきた。そこで、本稿では微粒子接合を応 用することにより難処理複合廃材のリサイクルに取り組ん だ事例についても説明する。具体例の一つとして、ガラス 纎維強化プラスチック (FRP) の $100 \%$ 有効利用による高性 能断熱材料開発への取り組みについて紹介したい。

\section{2. 微粒子接合プロセス}

筆者らが研究を進めてきた機械的手法による複合粒子作 製プロセスは、固体粒子を細かく砕く粉砕操作を機械的原 理として用いる。粉砕に伴う粒子の微細化や、粒子表面へ の機械的エネルギーの付与により、粒子表面の活性は高ま るため、この作用を利用すれば、外部加熱を施すことなく 乾式プロセスによって、粒子同士を接合して複合粒子を作 製することができる。実際にこれまでに粒子同士の複合化 に使用されたことのある機械的原理を調べてみると、微粉 砕機として用いられる原理のほぼすべてが、粒子複合化に 応用できることが分っている ${ }^{1)}$ 。なお複合粒子の量産化に おいては、複合化専用装置として開発された機種を用いる ことが多い。これらは、いずれも国内で開発されたもので ある ${ }^{1)}$

このような粒子複合化を制御する因子は、極めて多岐に 亘ると考えられるが、主に考慮すべき因子として、出発原 料粉体の条件と粉体を処理する際の機械的処理条件の二つ が挙げられる。前者においては、組み合わせる粒子の粒子 径や粒子特性（粒子形状、表面特性、機械的特性、融点など）、 さらに複合化する際の粒子の配合比などが挙げられる。一 方後者に関しては、機械的応力、処理温度、処理雲囲気、 処理時の粒子の添加手順などが挙げられる ${ }^{1)}$ 。

以上説明した微粒子接合プロセスを用いて、これまで筆 者らは Fig. 1 に示すような各種製造プロセスを開発した ${ }^{2)} 。$ まず (a)は、複合粒子製造プロセスであり、粒子の組み合 わせ、処理条件を制御することにより、核となる粒子表面

*大阪大学接合科学研究所スマートプロセス研究センター（† 567-0047 大阪府茨木市美穂ヶ 丘 11-1）

Smart Processing Research Center, Joining and Welding Research Institute, Osaka University (11-1 Mihogaoka, Ibaraki, Osaka, 567-0047 Japan) 


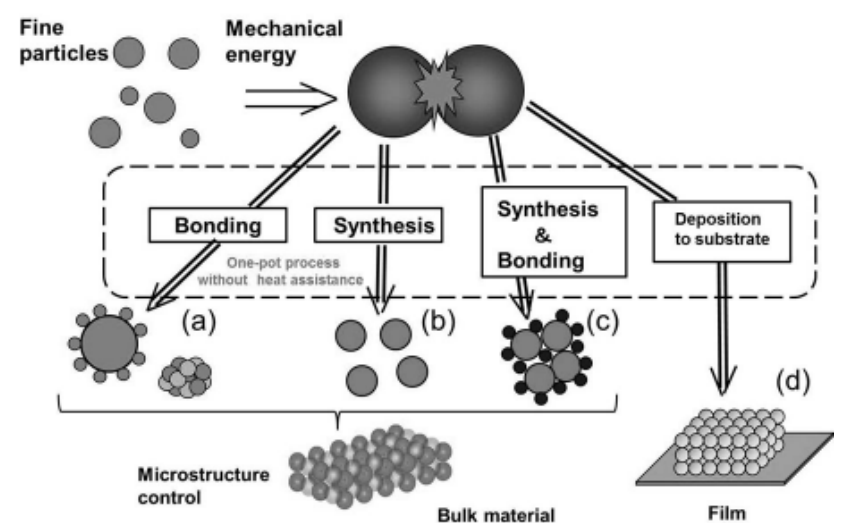

Fig. 1 Material design by one-pot mechanical processing based on particle bonding technology

に微粒子が接合した「被覆型複合粒子」や、微粒子同士が 接合してひとつの粒子を形成する「内部分散型複合粒子」 など、多様な構造の粒子を作製できる。このようにして作 製された複合粒子は、燃料電池など様々な分野において、 実用化に向けた研究が進められている ${ }^{3,4)}$ 。さらに、これ らの複合粒子の作製は、基本的には大気圧下、非加熱、ワ ンポットで行われるので、多品種少量生産などの高付加価 值製品の製造にも優位性のある製造技術であると期待され る。また粒子接合に用いる機械的原理を応用することによ り、(b)に示すように工業的に汎用されている原料粉体から 非加熱・ワンポットで各種ナノ粒子を合成することができ る。これまで、ランタンマンガン系複合酸化物 ${ }^{5}$ 、チタン 酸バリウムのなどのナノ粒子が、大気圧下で短時間、ワン ポットプロセスにて合成されている。さらに (c) は、(a) と (b) の二つのプロセスをワンポットで実現しようというもので ある。このプロセスは、合成された活物質のナノ粒子をリ チウムイオン電池の正極に高密度充填することを目的とし て開発されたものである ${ }^{7,8)}$ 。一方 (d) は、微粒子接合の機 能を、微粒子と基板との接合にも応用したものである。こ の方法では、基板表面に活性化された微粒子を順次積層す ることにより、ナノ構造の多孔質膜を作製しょうというも のである。この方法を用いて、固体酸化物形燃料電池 (SOFC) 電極の非加熱・ワンポットによる前駆体作製などの研究が 進められている9。

\section{3. 微粒子接合による高性能断熱材料の開発}

Fig. 2 は、Fig. 1(a)に示す微粒子接合プロセスを基礎と して開発した高性能断熱材料の製造プロセスである ${ }^{10)} 。$ 次粒子径が数 $\mathrm{nm}$ から数十 $\mathrm{nm}$ の粒子は、樹枝状（デンド ライト状）の凝集構造を形成することが多いが、この凝集 構造に機械的作用を施すことにより、図にみるように内部 に $100 \mathrm{~nm}$ 以下の気孔を持つ凝集体を作製することができ

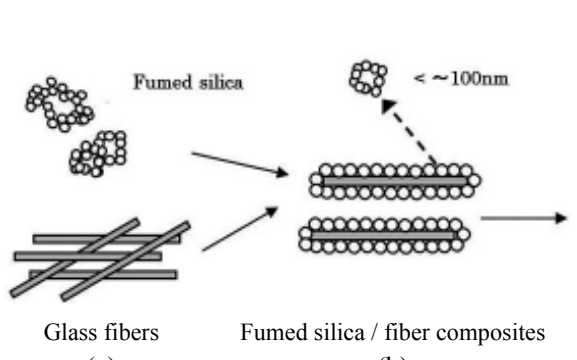

(a) (b)

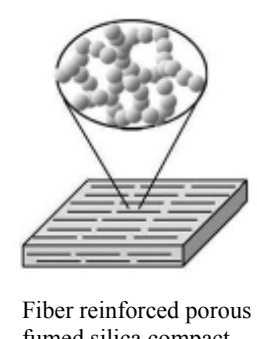

(c)
Fig. 2 Proposed method to fabricate fibrous fumed silica compacts: (a) mixing of raw materials, (b)particle bonding to coat glass fiber with fumed silica, (c) dry pressing of the composites from (b) to produce bulk body

Table 1 Thermal conductivity and apparent density of the fibrous fumed silica compacts prepared by particle bonding process

\begin{tabular}{ccccc}
\hline Specimen & $\begin{array}{c}\text { Density } \\
{[\mathrm{kg} / \mathrm{m} 3]}\end{array}$ & $\begin{array}{c}\text { Porosity } \\
{[\%]}\end{array}$ & \multicolumn{2}{c}{$\begin{array}{c}\text { Thermal Conductivity } \\
{[\mathrm{W} /(\mathrm{m} \cdot \mathrm{K})]}\end{array}$} \\
& & & $@ 100^{\circ} \mathrm{C}$ & $@ 400^{\circ} \mathrm{C}$ \\
\hline$\# 1$ & 459 & 81.2 & 0.0266 & 0.0269 \\
$\# 2$ & 485 & 80.1 & 0.0266 & 0.0282 \\
\hline
\end{tabular}

る。気孔径が数十 $\mathrm{nm}$ に達すると、粒子と同様に気孔に扮 いても、特異な性質が発現する。例えば、ナノ気孔を持つ 多孔体では対流伝熱が抑制されるために、高性能断熱材料 として利用できる。しかし、ナノ粒子集合体のみを加圧成 形することによってバルク材料を作製することは、極めて 困難である。そこで筆者らは、ガラス瀻維粒子表面にナノ 気孔を持つ凝集体を複合化して得られた複合瀻維粒子集合 体を、加圧成形により集積させることで、軽量で強度の高 い断熱材料を開発することに成功した。Table 1 は、Fig. 2 の方法で作製されたシリカ/ガラス緎維複合粒子の加圧 成形体の密度、空隙率、並びに熱伝導率を示したものであ る ${ }^{10)}$ 。ここで成形体密度は、加圧時の圧力により変化するが、 空隙率は $80 \%$ 以上に制御可能であり、極めて軽量である ことが分かる。また表にみるように、成形体の熱伝導率も $400{ }^{\circ} \mathrm{C}$ までは低い值を示している。

一方 Fig. 3 は、各種断熱材料の熱伝導率と温度との関係 を示したものである ${ }^{11}$ 。温度が高くなると、ふく射伝熱が 支配的になるため、眓に見るように温度とともに熱伝導率 は大きく増大する。そこで、高温でも適用可能な断熱材料 を開発するため、ここではシリカナノ粒子とガラス繊維の 複合粒子集合体に、さらに炭化ケイ素微粒子を分散させて

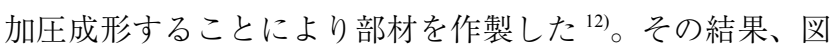
にみるように $800{ }^{\circ} \mathrm{C}$ 程度まで超低熱伝導率を有する高性能 断熱材料を開発することができた。またここでは示さない 


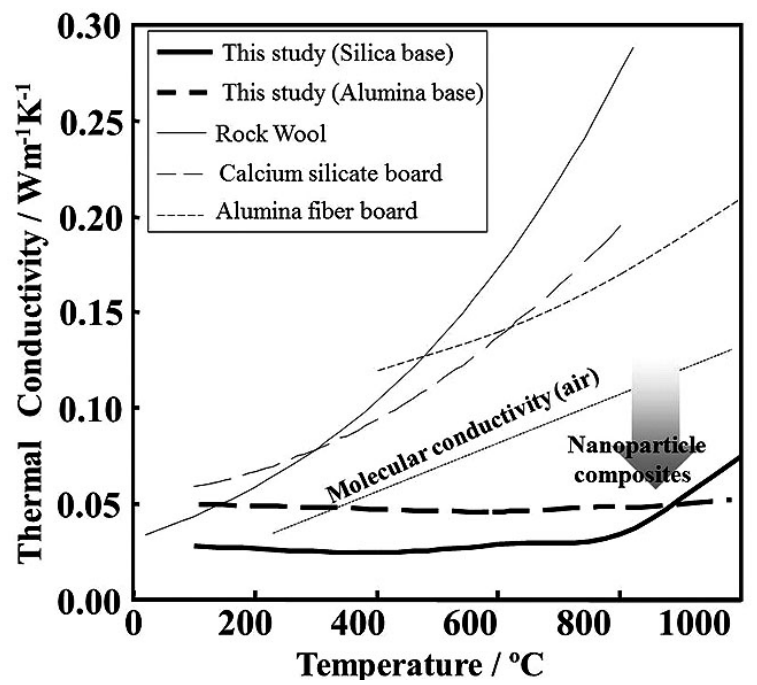

Fig. 3 Thermal conductivity of bulk bodies made by this method

が、得られた成形体はガラス瀻維で補強されているので、 機械加工により任意形状に加工可能であった。以上の研究 成果を基礎として、ニチアス株式会社より高性能断熱材料 が開発された。現在、「ロスリムボード」として、既に実用 化されており、軽量で低い熱伝導率を持ち、加工性の良い 断熱材料として注目されている。

\section{4. 難処理複合材料のリサイクルへの展開}

冒頭述べたように、筆者らは材料界面の接合に加えてそ の分離という観点から、リサイクルが困難である複合材料 の新しい循環利用に向けたアプローチをこれまで展開して きた。Fig. 4 は、そのコンセプトを示したものである ${ }^{13) 。}$ 図中の従来のリサイクルのループは、高いエネルギーコス 卜をかけて複合廃材を元の材料にリサイクルしようという ものである。しかし、このようにしてリサイクルされた材 料はコストが高く、未使用のものに加えて品質が劣るため、 その利用普及を進めるのは極めて困難である。

一方 Fig. 4 のコンセプトは、図中の新規リサイクルのルー プにみるように、複合材料の持つ構造を積極的に活用して、 それを新たな素材と巧みに組み合わせることにより、元の 廃材とは異なる機能を持つ新複合材料を創製しようという ものである。廃材の構造を極力活用するため、従来のリサ イクルと比較して、莫大なエネルギーの使用は不要である。 また、理想的には廃材の $100 \%$ 利用を目指すものである。 このようにして再生した複合材料に新たな機能が付与され れば、再生材料の普及は大きく広がっていくだろう。その 結果、新材料への転換も大きく進むものと期待される。

ここでは一例として、この技術を活用して、難処理複合 廃材の代表例であるガラス瀻維強化プラスチック廃材 (以 下 FRP と記す）の循環利用プロセスへ展開した事例を紹

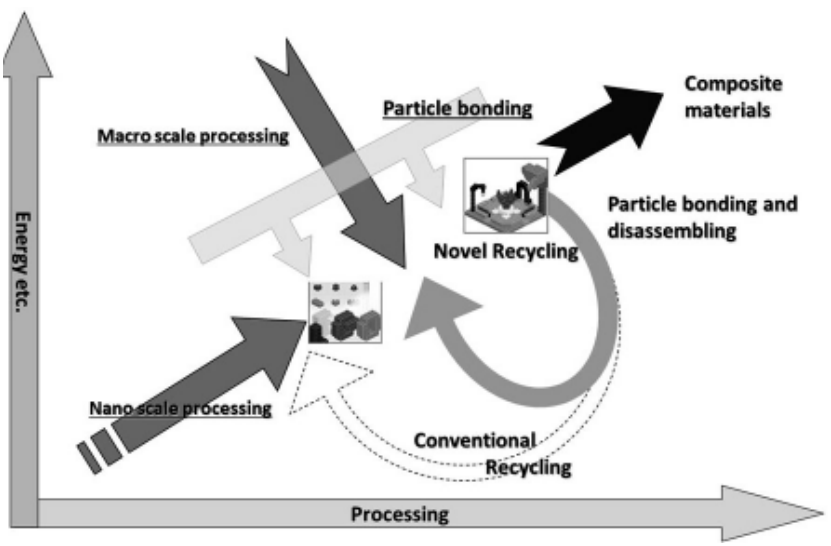

Fig. 4 Concept of new recycling for composite materials based on particle bonding principle

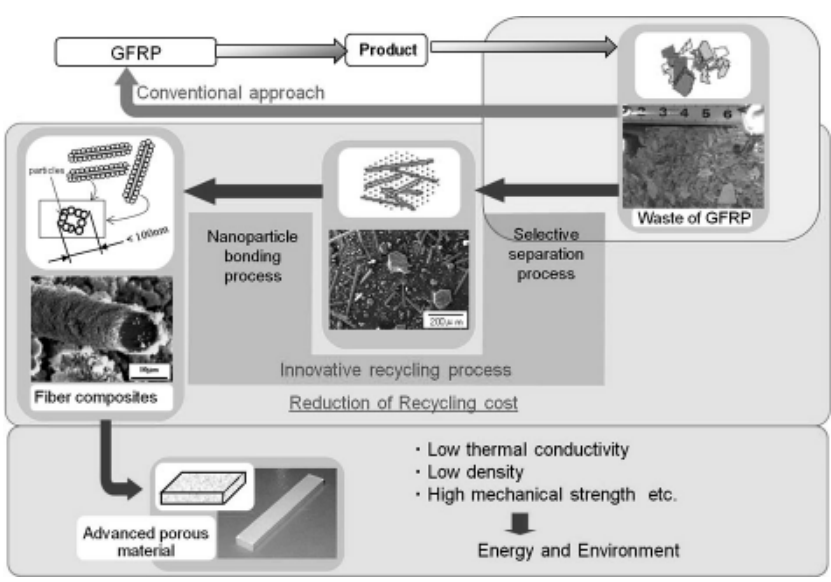

Fig. 5 New recycling process of FRP for advanced materials

介する。筆者らが株 INAX（現在、(陎 LIXIL）と共同で開 発した浴槽用に使用される FRP 廃材の新規循環プロセスを Fig. 5 に示す ${ }^{13)}$ 。FRP 廃材は我が国でも年間約 45 万トン 発生するが、そのリサイクルには膨大なエネルギーを要す ることから、そのほとんどが焼却や埋め立て処理されてい る ${ }^{13)}$ 。そこで筆者らは、省資源、省エネルギー、さらには 地球温暖化防止の観点から、FRP 廃材を元の素材に戻すの ではなく、廃材の構造を組み替えてその全量を再利用する 新しい循環プロセスを提案した。

具体的には Fig. 5 にみるように、まず FRP を構成するガ ラス瀻維をその形状を保ったままでマトリックス樹脂から 剥がした後に、ガラス繊維表面に新たにシリカナノ粒子を 多孔質状に複合化し、マトリックス樹脂との混合状態のま ま加圧成形する。その結果、軽量で超低熱伝導率の断熱材 料を作製することができる。Fig. 6 に、このプロセスによ り得られた部材の熱伝導率を測定した結果を示す ${ }^{144}$ 。図よ 


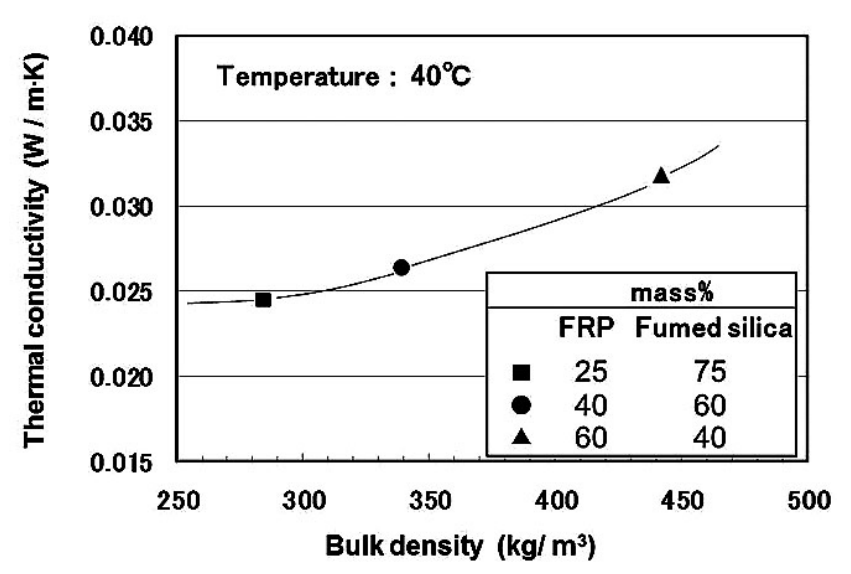

Fig. 6 Relationship between thermal conductivity and bulk density of porous compacts made by the process as shown in Fig. 5

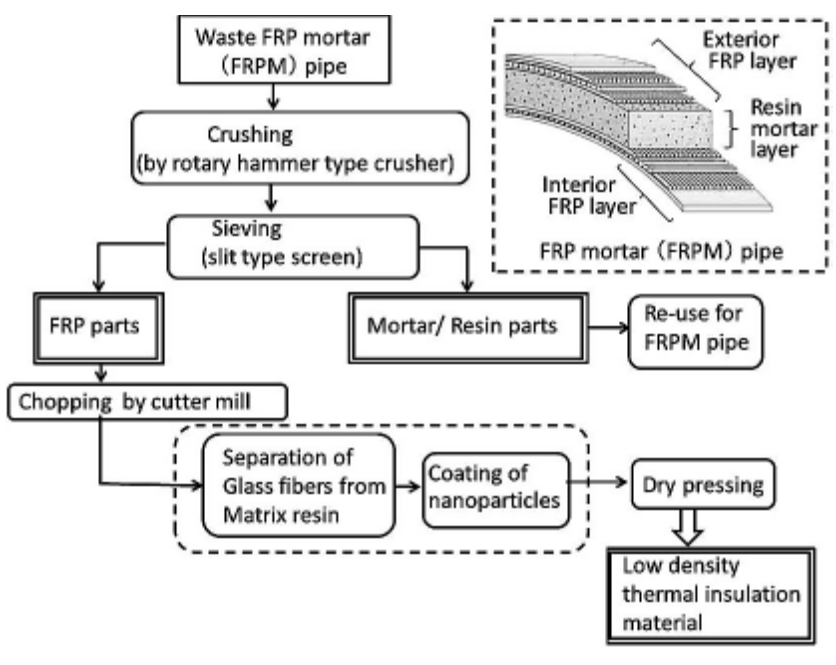

Fig. 7 New recycling process of waste FRP mortar pipe.

\section{5. まとめ}

以上本稿では、筆者らが開発した大気圧下、非加熱、ワ ンポットプロセスを説明するとともに、実用化までに至っ た事例として、微粒子接合により開発された高性能断熱材 料を紹介した。また、すべての材料に共通の課題である材 料の循環利用プロセスについても取り上げ、筆者らが取り 組んでいる材料界面の接合と分離を基礎とする難処理複合 材料のリサイクルへの取り組みについて説明した。今後も、 微粒子接合を基礎として、さらにスマートな微粒子製造プ ロセスを開発するとともに、新材料の開発を進めて行きた いと考えている。

\section{引用文献}

1) M. Naito, A. Kondo, and T. Yokoyama: ISIJ International, 33 (1993) 915-924.

2) 内藤牧男 : 化学装置 . 55-10 (2013) 55-59.

3) A. Hagiwara, N. Hobara, K. Takizawa, K. Sato, H. Abe, and M. Naito: Solid State Ionics, 177 (2006) 2967-2977.

4) K. Sato, H. Abe, T. Misono, K. Murata, T. Fukui, and M. Naito: J.European Ceram. Soc. 29 (2009) 1119-1124.

5) K. Sato, J. Chaichanawong, H. Abe, and M. Naito: Material Letters, 60 (2006) 1399-1402.

6) A. Kondo, K .Sato, H. Abe, M. Naito, and H. Shimoda : Ceramic Transactions, 198 (2007) 375-380.

7) J. Yoshida, M. Stark, J. Holzbock, N. Huesing, S. Nakanishi, H. Iba, H .Abe, and M. Naito: J. Power Sources, 226 (2013) 122-126.

8) J. Yoshida, A. Kondo, S. Nakanishi, H. Iba, H. Abe, and M. Naito: Advanced Powder Technology, 24 (2013) 829-832.

9) H. Abe, M. Naito, and K. Sato: Int. J. Appl. Ceram. Technol., 9 (2012) 928-935.

10) H. Abe, I. Abe, K. Sato, and M. Naito : J. Am. Ceram. Soc., 88 (2005) 
微粒子接合による高性能断熱材料の開発と材料リサイクルへの展開（近藤・阿部・内藤）

1359-1361.

11）内藤牧男、牧野尚夫、多々見純一、米屋勝利・編：“入門粉体 材料設計”、日刊工業新聞社、(2011) 220-228.

12) 大村高弘、伊藤素男、阿部勇美、阿部浩也、内藤牧男 : 粉体 工学会誌 , 46 (2009) 806-812.

13) 内藤牧男、牧野尚夫・編：“粉体技術が挑む究極のエネルギー と環境調和”、日刊工業新聞社、(2010) 157-164.
14）近藤 光、阿部浩也、井須紀文、三浦正嗣、森 梓、大村高弘、 内藤牧男：粉体工学会誌, 47 (2010) 768-772.

15) 内藤牧男、阿部浩也、近藤 光：強化プラスチックス、58-10 (2012) 320-324.

16) 近藤 光、大村高弘、阿部浩也、加納純也、内藤牧男：粉体 工学会誌、49 (2012) 827-831. 